\title{
The Effect of Clove Oil Supplementation in Laying Hen Diets on Performance, Egg Quality, Some Blood Parameters, and Yolk TBARS
}

\author{
Melek Şehitoğlu ${ }^{1, a}$, Hatice Kaya ${ }^{1, b, *}$ \\ ${ }^{I}$ Department of Animal Science, Agricultural Faculty, Atatürk University, 25030 Erzurum, Turkey \\ *Corresponding author \\ A R T I C L E I N F O A B S T R A C T \\ Research Article \\ In this study, it was investigated the effect of clove oil supplementation at increasing levels into \\ laying hens' diets on performance, egg quality traits, some blood parameters and yolk TBARS \\ (Thiobarbituric Acid Reagent) values. For this purpose 96 Lohman white laying hens, 28 weeks of \\ age, were divided into four treatment groups. Control group was fed with basal diet (C) and \\ treatment groups were fed with diets formed by addition of clove oil at $50 \mathrm{ppm}(\mathrm{CO} 1), 100 \mathrm{ppm}$ \\ $(\mathrm{CO} 2)$ and $150 \mathrm{ppm}(\mathrm{CO} 3)$, respectively. During the trial, feed and water were given as ad-libitum, \\ and poultry house was illuminated for 17 hours. Experiment lasted for 13 weeks. Addition clove oil \\ at increasing rates into diet did not affect the live weight. The data analysed as polynomial showed \\ that supplementation of clove oil into layer diet linearly improved feed conversion ratio and \\ increased the egg production. But, daily feed consumption, egg weight, damaged egg ratio and egg \\ quality parameters were not affected by treatments. Serum parameters such as triglyceride, glucose, \\ aspartate aminotransferase, alanine aminotransferase and calcium were not affected by the clove oil \\ supplementation. TBARS values in $\mathrm{C}, \mathrm{CO} 1$, and $\mathrm{CO} 2$ were found higher than the $\mathrm{CO} 3$ group fed \\ with diet including $150 \mathrm{ppm}$ clove oil. In conclusion, clove oil at $150 \mathrm{ppm}$ level in diets of laying \\ Keywords:
Laying hen \\ Clove oil \\ Performance \\ Egg quality \\ Blood parameters \\ hens could be used due to extend the egg shelf life and to decline serum cholesterol content.
}

\section{Introduction}

Antibiotics have been used in poultry feeds over the years to improve growth performance, prevent some specific pathogenic microorganism, and increase some beneficial microorganisms in intestinal microflora (Mohammadi et al., 2014). However, with the public becoming increasingly concerned about the risk of a rise in antibiotic resistant bacteria, producers have faced objections to the presence of such antibiotics in livestock feeds (Arpášová et al., 2017). After the EU banned antibiotics from animal feed in 2006, the search was on to find substitutes, particularly in respect to egg quality and egg production (Kaya et al., 2015). In recent years, products containing essential oils derived from a number of spices and herbs are used as growth promoting feed additives in animal nutrition, but more studies are needed to optimize their use (Mohammadi et al., 2014).

Recently, herbs have come to be viewed as possible substitutes for antibiotics and one of the most efficient is clove (Syzygium aromaticum), belonging to the family Myrtaceae. The ingredients in clove oil (CO) including eugenol, isoeugenol, caryophyllene, $\alpha$-humulene, and eugenyl acetate are viewed as particularly valuable. Eugenol is the most biologically active compound in cloves and makes up 70-80\% of clove oil (Al-Mufarrej et al., 2019). Eugenol is a substance found in clove oil that has anti-microbial and anti-inflammatory properties and flavoids that boost its anti-inflammatory abilities (Mukhtar, 2011).

It has been stated that the components of clove have strong antibacterial, antiseptic, appetite and digestion stimulation, antimicrobial and antifungal, analgesic and anti-inflammatory and anticarcinogenic, antiparasitic and antioxidant properties (Mukhtar, 2011). Ingredients with good nutritional value including natural antioxidants, essential fatty acids, and lipid-soluble bioactive molecules are found in cold pressed clove oil (Hussein et al., 2019). Thus, in this study, research was carried out to determine the effect of increasing the dietary levels $(50,100,150$ $\mathrm{ppm})$ of clove oil to examine its natural antioxidant effects and its effect on performance, egg quality traits, some blood parameters, and yolk TBARS (Thiobarbituric Acid Reagent) values for laying hens. 


\section{Materials and Methods}

\section{Animals, Diet, and Management}

The Research Animal Ethics Committee of Atatürk University approved this experimental protocol. The animal subjects of the study were ninety-six Lohmann white laying hens. They were divided into four groups randomly. Six subgroups of four hens each were created from each of the above groups and housed in identical cages $(50 \times 46 \times 46 \mathrm{~cm})$. After a one-week period to allow the hens to adapt, they were fed for 12 weeks with a diet containing varying amounts of clove oil (CO) or no additives. Experimental groups were fed standard commercial layer diet (control), without clove oil addition, or control with the inclusion of clove oil at $50 \mathrm{ppm}(\mathrm{CO} 1)$, $100 \mathrm{ppm}(\mathrm{CO} 2)$, and $150 \mathrm{ppm}(\mathrm{CO} 3)$. The $\mathrm{CO}$ added in different amounts to the basal was obtained from Aksu Vital Doğal Ürünler Gıda San. \& Tic. Lt. The basal diet was formulated to meet nutrient requirements proposed by NRC (1994). AOAC (2000) methods were used to analyse the experimental diets. Chemical compositions of the basal diet, the CO as well as their ingredients, may be seen in Table 1. During the 12 weeks of the experiment, the hens were fed at 08:30 once per day, had water available all the time, and were exposed to light for $17 \mathrm{~h}$ per day.

\section{Sample Collection and Analytical Procedure}

The hens were weighed at the beginning and the end of the experiment. The daily feed consumption and number of laid eggs was recorded. The feed conversion ratio (FCR) calculated by one kilogram of feed consumed per kilogram of eggs produced. Once per month, the eggs laid by the hens were gathered ( $\mathrm{n}=12$ per group); they were kept for $24 \mathrm{~h}$ at room temperature in order to evaluate egg quality parameters including shape index (SI), shell strength (SS) (determined by using a machine with a spiral pressure system), shell thickness (ST) (determined in three different parts by using a micrometer), albumen index (AI), yolk index (YI), yolk color (YC) (the Yolk Color Fan, the CIE standard colorimetric system, F. Hoffman-La Roche Ltd., Basel, Switzerland), and Haugh unit (HU). The Kaya and Macit method (2012) was used in the assessment.

Bloods were collected in a sample amount of $5.0 \mathrm{~mL}$ from the axillary vein of 24 hens (six from each group) at the end of the experiment period. These were placed into non-heparinized tubes using sterilized needles. Incubation of these samples took place at $37^{\circ} \mathrm{C}$ for $2 \mathrm{~h}$, and then they were centrifuged at $3000 \mathrm{rpm}$ for five min. While the serum parameters were being determined, the samples were stored in $1.5 \mathrm{~mL}$ Eppendorf tubes at $-80{ }^{\circ} \mathrm{C}$. These serum parameters including cholesterol, triglycerides, glucose, total protein, albumin, alanine aminotransferase (ALT), aspartate aminotransferase (AST), alkaline phosphatase (ALP) $\mathrm{Ca}, \mathrm{P}$, and $\mathrm{Mg}$ were measured using commercial kits (DDS ${ }^{\circledR}$ Spectrophotometric Kits, Diasis Diagnostic Systems Co., İstanbul, Turkey) with the Autoanalyzer Mindray Perfect Plus 400.

An index of lipid peroxidation provided the basis for the evaluation of the malondialdehyde (MDA) formed during refrigerated storage (Kaya et al., 2014). 24 eggs from each group were selected, shelled, and stored for 0,7 , 14,28 , and 56 days at $+4^{\circ} \mathrm{C}$ to determine the MDA in the yolk. At this point, the method of Placer et al. (1966) was used with a Biotek ELISA Reader (Bio Tek $\mu$ Quant MQX200 Elisa Reader, USA) to analyze the samples. According to the method, the egg homogenate was prepared by taking 3-5 grams of egg yolk and diluting it with $0.9 \% \mathrm{NaCl}$ at a ratio of $1 / 9.2 .25 \mathrm{ml}$ of color reagent was added on $250 \mu \mathrm{l} \mathrm{egg} \mathrm{homogenate.} \mathrm{This} \mathrm{mixture} \mathrm{was}$ kept in a boiling water bath for $20 \mathrm{~min}$, then cooled and centrifuged at 2,000 rpm for $5 \mathrm{~min}$, and the absorbance was measured at $532 \mathrm{~nm}$, and thiobarbituric acid reagent (TBARS) values were determined as micrograms of MDA per gram of yolk. The egg yolk TBARS value was calculated using the formula below:

$($ TBARS) $(\mathrm{ng} / \mathrm{mg})=356.1 \times$ absorbance value

\section{Statistical Analysis}

The ANOVA by means of the GLM procedure of SPSS 10.0 software (2011) was used on the data. To determine the effect of the feeding level of clove oil in the diets, a polynomial contrast was created. A significance level at $\mathrm{P}<0.05$ for the effects of the dietary treatments on response variables was established.

Table 1. Analysed Chemical composition of the experimental diets

\begin{tabular}{l|c}
\hline \multicolumn{2}{c}{ Ingredient, (\%) } \\
\hline Corn & 59.63 \\
Soybean meal (46\% CP) & 19.50 \\
Sunflower seed meal (\%36 CP) & 7.40 \\
Soybean oil & 1.49 \\
Meat-bone meal & 1.50 \\
Monocalcium phosphate & 0.07 \\
Marble & 9.50 \\
Vitamin-mineral premix ${ }^{1}$ & 0.30 \\
Salt (NaCl) & 0.20 \\
Sodium bicarbonate & 0.15 \\
Ekobond (Toxin binder) & 0.10 \\
Salmonil LCT (Organic Acid Mixture) & 0.10 \\
DL-Methionine & 0.06 \\
\hline \multicolumn{2}{c}{ (on a DM basis) } \\
\hline Dry matter (\%) & 88.36 \\
Crude protein (\%) & 17.58 \\
Crude fiber (\%) & 3.19 \\
Ether extract (\%) & 13.75 \\
Crude Ash (\%) & 3.77 \\
Calcium (\%) & 3.80 \\
Phosphorus (\%) & 0.47 \\
ME ${ }^{2}$ (kcal/kg) & 2724 \\
\hline
\end{tabular}

${ }^{1}$ The premix provided per $1 \mathrm{~kg}$ of diet: 4.000 .000 IU Vitamin A; 800.000 IU Vitamin D3,10.000 mg Vitamin E; $100.000 \mathrm{mg}$ Choline chloride; $26.667 \mathrm{mg}$ Manganese oxide; $20.000 \mathrm{mg}$ Zinc oxide; $20.000 \mathrm{mg}$ Iron sulfate; $1.667 \mathrm{mg}$ Copper sulfate; $333 \mathrm{mg}$ Calcium iodate; $50 \mathrm{mg}$ Sodium selenite; $300 \mathrm{mg}$ Hydroxy methionine. ${ }^{2} \mathrm{ME}$ : Metabolizable energy value calculated according to TSE (1991)

\section{Results and Discussion}

\section{Laying Performance}

The effects of addition different levels $(0,50,100,150$ ppm) of clove oil in diet, as a natural antioxidants, on the Lohmann white layers performance parameters are presented in Table 2. 
Table 2. Performance parameters of the control and clove oil groups

\begin{tabular}{|c|c|c|c|c|c|c|c|}
\hline \multirow[b]{2}{*}{ Treatment } & \multirow{2}{*}{$\begin{array}{c}\text { Feed } \\
\text { Consumption } \\
(\mathrm{g} / \mathrm{d})\end{array}$} & \multirow{2}{*}{$\begin{array}{c}\text { Egg } \\
\text { Production } \\
(\%)\end{array}$} & \multirow{2}{*}{$\begin{array}{c}\text { Egg } \\
\text { Weight } \\
\text { (g) }\end{array}$} & \multirow{2}{*}{$\begin{array}{c}\text { FCR } \\
(\mathrm{kg} \mathrm{feed} / \mathrm{kg} \mathrm{egg})\end{array}$} & \multicolumn{3}{|c|}{ Body weigth (g) } \\
\hline & & & & & Initial & Final & Change \\
\hline Control & 119.01 & 91.02 & 66.31 & 1.97 & 1615.62 & 1716.57 & 100.93 \\
\hline $\mathrm{CO} 1$ & 117.39 & 93.99 & 65.95 & 1.89 & 1611.67 & 1697.07 & 85.84 \\
\hline $\mathrm{CO} 2$ & 117.16 & 94.84 & 65.83 & 1.88 & 1621.7 & 1704.88 & 83.21 \\
\hline $\mathrm{CO} 3$ & 116.53 & 94.94 & 66.11 & 1.86 & 1612.7 & 1739.37 & 126.67 \\
\hline SEM & 1.74 & 0.76 & 0.80 & 0.04 & 25.86 & 31.56 & 20.20 \\
\hline \multicolumn{8}{|c|}{ Polinomial Analyses } \\
\hline $\mathrm{L}$ & 0.480 & 0.007 & 0.841 & 0.009 & 0.991 & 0.595 & 0.416 \\
\hline $\mathrm{Q}$ & 0.494 & 0.066 & 0.692 & 0.580 & 0.924 & 0.403 & 0.160 \\
\hline $\mathrm{C}$ & 0.767 & 0.080 & 0.963 & 0.661 & 0.779 & 0.996 & 0.725 \\
\hline
\end{tabular}

$\mathrm{CO} 1=50$ ppm Clove Oil, $\mathrm{CO} 2=100$ ppm Clove oil, $\mathrm{CO} 3=150 \mathrm{ppm}$ Clove Oil, L=Linear, Q=Quadratic, C=Cubic

$\mathrm{SEM}=$ Standart error mean, FCR: Feed Conversion Ratio

Table 3. Egg quality parameters of the control and clove oil groups

\begin{tabular}{|c|c|c|c|c|c|c|c|c|c|}
\hline Groups & $\begin{array}{c}\text { Egg } \\
\text { Weight } \\
(\mathrm{g})\end{array}$ & $\begin{array}{c}\text { Shape } \\
\text { Index } \\
(\%) \\
\end{array}$ & $\begin{array}{c}\text { Shell } \\
\text { Strength } \\
\left(\mathrm{kg} / \mathrm{cm}^{2}\right)\end{array}$ & $\begin{array}{c}\text { Shell } \\
\text { Thickness } \\
\left(\mathrm{cm} \times 10^{-2}\right)\end{array}$ & $\begin{array}{c}\text { Shell } \\
\text { Weight } \\
(\mathrm{g})\end{array}$ & $\begin{array}{c}\text { Yolk } \\
\text { Colour }\end{array}$ & $\begin{array}{c}\text { Yolk } \\
\text { Index } \\
(\%) \\
\end{array}$ & $\begin{array}{c}\text { Albumen } \\
\text { Index } \\
(\%)\end{array}$ & $\begin{array}{l}\text { Haugh } \\
\text { Unit }\end{array}$ \\
\hline Control & 66.25 & 74.11 & 3.43 & 0.396 & 8.84 & 12.02 & 42.42 & 9.96 & 89.08 \\
\hline $\mathrm{CO} 1$ & 66.34 & 72.72 & 3.27 & 0.393 & 8.56 & 11.70 & 43.56 & 10.22 & 88.90 \\
\hline $\mathrm{CO} 2$ & 67.00 & 73.58 & 2.89 & 0.384 & 8.54 & 11.83 & 42.63 & 10.27 & 88.59 \\
\hline $\mathrm{CO} 3$ & 64.64 & 72.75 & 3.13 & 0.379 & 8.20 & 11.63 & 43.49 & 10.08 & 89.59 \\
\hline SEM & 1.46 & 0.59 & 0.23 & 0.01 & 0.17 & 0.15 & 0.80 & 0.39 & 1.53 \\
\hline \multicolumn{10}{|c|}{ Polinomial Analyses } \\
\hline $\mathrm{L}$ & 0.528 & 0.233 & 0.216 & 0.056 & 0.084 & 0.125 & 0.528 & 0.811 & 0.858 \\
\hline Q & 0.410 & 0.640 & 0.380 & 0.859 & 0.896 & 0.668 & 0.866 & 0.574 & 0.702 \\
\hline $\mathrm{C}$ & 0.589 & 0.147 & 0.418 & 0.626 & 0.602 & 0.240 & 0.290 & 0.985 & 0.837 \\
\hline
\end{tabular}

$\mathrm{CO} 1=50$ ppm Clove Oil, CO2=100 ppm Clove oil, CO3=150 ppm Clove Oil, L=Linear, Q=Quadratic, C=Cubic, SEM = Standart error mean.

According to the results of polynomial analysis, it was observed that there was no effect in feed consumption in parallel with the increase of clove oil added to the ration. Mukhtar (2011) showed an increase in the feed intake by broiler chicks fed with $600 \mathrm{mg}$ clove oil $/ \mathrm{kg}$ as compared with those from the control, $200 \mathrm{mg} / \mathrm{kg}$ and $400 \mathrm{mg} / \mathrm{kg}$ clove oil groups, but this increase was not significant $(\mathrm{P}>0.05)$. In another experiment, Hussein et al. (2019) reported that increasing clove oil levels $(0,0.75$, and 1.5 $\mathrm{mL} / \mathrm{kg}$ ) gradually increased feed intake in japanese quails. Similar to the findings from the current study, Gandomani et al. (2014) reported that adding clove buds to different levels $(0.2 \%$, and $0.4 \%)$ of laying hens and broiler does not affect daily feed consumption.

Hens fed the control diet producted less egg than birds fed the clove oil supplemented diets in this study. In response to increasing level of clove oil supplementation, egg production linearly increased. This results are in contrast with those Arpášová et al. (2017) who introduced that the addition of $0.3 \mathrm{ml} \mathrm{kg}^{-1}, 0.6 \mathrm{ml} \mathrm{kg}^{-1}$, and $1 \mathrm{ml} \mathrm{kg}^{-1}$ clove oils into hens' diet had no significantly different to the egg production. Similar to the present study, Gandomani et al. (2014) found that the addition of different levels $(0.2$ and $0.4 \%)$ of clove bud to laying hen feeds increased egg production. Essential oils' functions is based on organoleptic effect and stimulation of organism to the production of digestive juices due to consisted compounds. As a result, higher nutrient digestibility and absorption were observed (Arpášová et al., 2017).
As shown in Table 2, clove oil supplementation at increasing levels into diet of laying hens had a statistically significant effect on FCR, which could be attributed to enhanced nutrient utilization. In response to increasing level of clove oil supplementation, FCR linearly decreased $(\mathrm{P}<0.05)$. Feed utilization rate was more important performance parameter than feed intake.

This may be due to the stimulation mechanisms of digestive enzyme secretion and the ecosystem stabilization of the gut microflora, leading to improved feed utilization (Zhai et al., 2018). In addition, many studies have confirmed the positive effect of clove oil on FCR (Mukhtar, 2011; Hussein et al., 2019).

\section{Egg Quality Parameters}

As can be seen from Table 3, according to the results of polynomial analysis, none of the egg quality parameters including SI, SS, ST, AI, YI, YC and HU was affected by increasing level of clove oil (50, 100, 150 ppm) supplementation. It expressed similarly with this study that the addition of clove essential oil supplementation $(0.3,0.6$ and $1 \mathrm{mg} \mathrm{kg}^{-1}$ ) to diets had not a significant effect on yolk index, yolk colour but unlike this study the albumen index significantly $(\mathrm{P}<0.05)$ influenced by the addition of $1 \mathrm{ml}$ $\mathrm{kg}^{-1}$ clove oil. Also, Haugh units were significantly influenced $(\mathrm{P}<0.05)$ by the addition of $0.6 \mathrm{ml} \mathrm{kg}^{-1}$ and 1 $\mathrm{mg} / \mathrm{kg}$ clove oil (Arpášová et al., 2017). These results agree with those of Gandomani et al. (2014), who reported that SI, SS, ST, AI, YI, YC and HU were not influenced by increasing dietary clove bud content. Also the same 


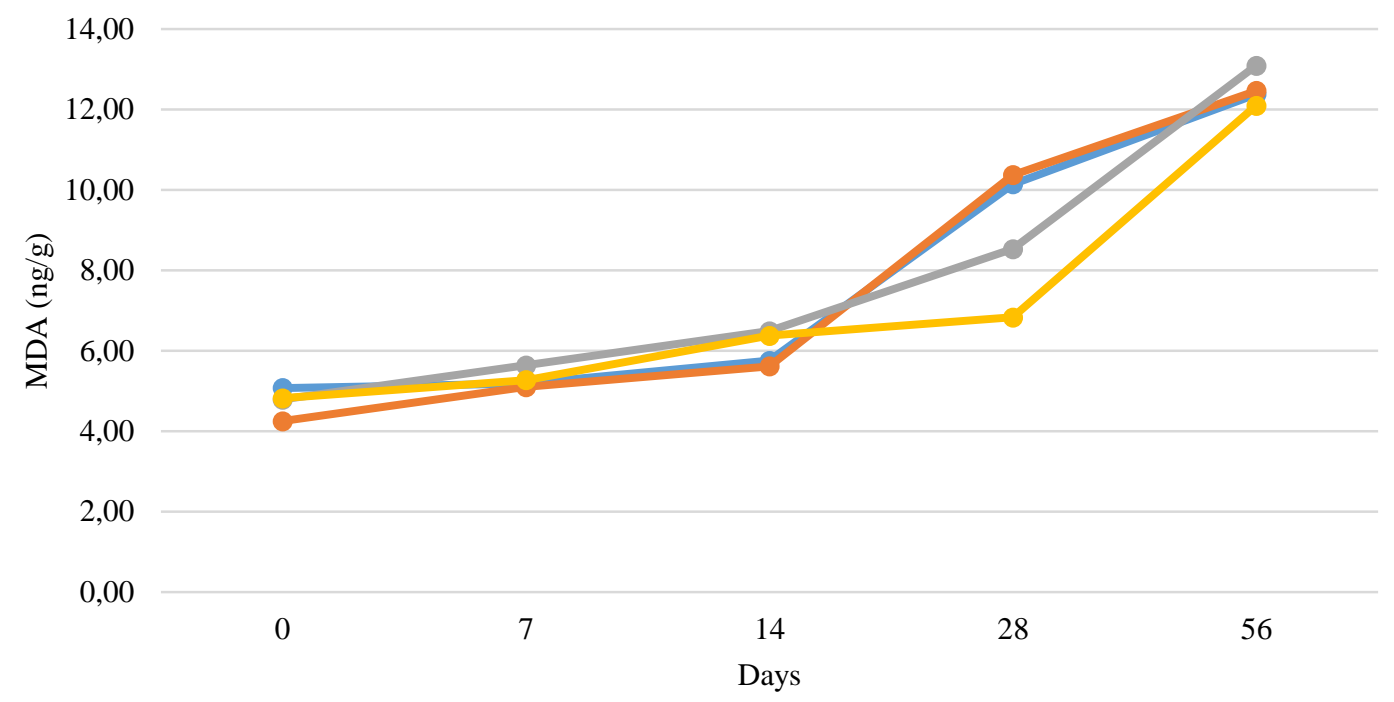

Figure 1. The effect of storage time and level on TBARS value

Phenolic compounds, due to phenol structures or phenolic sequences in molecular structures, give rise to hydrogen from phenolic hydroxyl groups and prevent oxidation by inhibiting the formation of free fatty acid radicals at the beginning (Saricaoglu and Turhan, 2018). It is considered that the antioxidant capacity of $\mathrm{CO}$ is highly related to eugenol content (Saricaoglu and Turhan, 2018). CO contain eugenol (90 to $95 \%$ of oil content), a potent polyphenolic compound and is known to exhibit pharmacological properties such as antioxidant (Hussein et al., 2019).

Also it reported that using the highest level of clove bud (levels of clove bud $0.0,2.0$, and $4.0 \mathrm{~g} / \mathrm{kg}$ ) led to decline the MDA content of egg yolk in eggs kept for $30 \mathrm{~d}$ in the refrigerator and for $15 \mathrm{~d}$ in storage conditions (Alizadeh et al., 2015). In another study, it stated that oxidative stability of hen liver was enhanced by essential oil mixture, thereby increasing hepatic antioxidant enzymes (i.e., superoxide dismutase and glutathione peroxidase) compared to those of the control group (Bozkurt et al., 2012). Antioxidant is defense system that provide a strong defense against the destructive effects of free radicals which are affect many compounds and molecules present on the cell membranes. Lipid peroxidation is the chain of reactions of oxidative degradation of lipids. Malondialdehyde (MDA) is one of the most known secondary products of lipid peroxidation (Iskender et al., 2016).

\section{Conclusion}

In recent years, researchers have been focused on natural antioxidant additives such as essential oils. This study reveals that clove oil exhibit remarkable antioxidant capacity. In conclusion, clove oil at $150 \mathrm{ppm}$ level in diets of laying hens might be used due to extend the egg shelf life and to decline serum cholesterol content.

\section{Acknowledgements}

This study was taken from the part of Melek Şehitoğlu's master thesis.

\section{References}

Alizadeh MR, Mahdavi AH, Rahmani HR, Jahanian EMR. 2015. Effects of different levels of clove bud (Syzygium aromaticum) on yolk biochemical parameters and fatty acids profile, yolk oxidative stability, and ovarian follicle numbers of laying hens receiving different $n-6$ to $n-3$ ratios. Animal Feed Science and Technology, 206: 67-75. https://doi.org/10.1016/j.anifeedsci.2015.05.007

Al-Mufarrej SI, Fazea EH, Al-Baadani HH, Qaid MM. 2019. Effects of clove powder supplementation on performance, blood biochemistry, and immune responses in broiler chickens. South African Journal of Animal Science, 49: 835844. http://dx.doi.org/10.4314/sajas.v49i5.6.

AOAC. 2000. Official Methods of Analysis. (17th Ed.) Maryland, USA: Association of Official Analytical Chemists.

Arpášová H, Gálik B, Fik M, Pistová, V. 2017. The Effect of the clove essential oil to the production and quality of laying hens eggs. Scientific Papers: Animal Science and Biotechnologies, 50: 1-5.

Bozkurt M, Tokuşoğlu Ö, Küçükyılmaz K, Akşit H, Çabuk M, Çatlı AU, Seyrek K, Çınar M. 2012. Effects of dietary mannanoligosaccharide and herbal essential oil blend supplementation on performance and oxidative stability of eggs and liver in laying hens. Italian Journal of Animal Science, 11: 223-229. https://doi.org/10.4081/ijas.2012.e41

Chowdhury S, Mandal GP, Patra AK, Kumar P, Samanta I, Pradhan S., Samanta AK. 2018. Different essential oils in diets of broiler chickens: 2. Gut microbes and morphology, immune response, and some blood profile and antioxidant enzymes. Animal Feed Science and Technology, 236: 39-47. https://doi.org/10.1016/j.anifeedsci.2017.12.003

Gandomani VT, Mahdavi AH, Rahmani HR, Riasi A, Jahanian E. 2014. Effects of different levels of clove bud (Syzygium aromaticum) on performance, intestinal microbial colonization, jejunal morphology, and immunocompetence of laying hens fed different $\mathrm{n} 6$ to $\mathrm{n}-3$ ratios. Livestock Science, 167: 236-248. https://doi.org/10.1016/j.livsci.2014.05.006

Gülçin I, Elmastas M, Aboul-Enein HY. 2012. Antioxidant activity of clove oil - A powerful antioxidant source. Arabian Journal of Chemistry. 5: 489-499. https://doi.org/10.1016/j.arabjc.2010.09.016

Hussein MMA, Abd El-Hack ME, Mahgoub SA, Saadeldin IM, Swelum AA. 2019. Effects of clove (Syzygium aromaticum) oil on quail growth, carcass traits, blood components, meat quality, and intestinal microbiota. Poultry Science, 98:319329. https://doi.org/10.3382/ps/pey348 
Iskender H, Yenice G, Dokumacioglu E, Kaynar O, Hayirli A, Kaya A. 2016. The effects of dietary flavonoid supplementation on the antioxidant status of laying hens. Brazilian Journal of Poultry Science, 18: 663-668. https://doi.org/10.1590/1806-9061-2016-0356

Kaya A, Kaya H, Gül M, Apaydin Yıldırım B, Timurkaan S. 2015. Effect of different levels of organic acids in the diets of hens on laying performance, egg quality criteria, blood parameters, and intestinal histomorphology. Indian Journal of Animal Research, 49: 645-651. DOI: 10.18805/ijar.5577.

Kaya A, Apaydın Yıldırım B, Kaya H, Gül M, Çelebi Ş. 2014. The effects of diets supplemented with crushed and extracted grape seed on performance, egg quality parameters, yolk peroxidation and serum traits in laying hens. European Poultry Science, 78. DOI: 10.1399/eps.2014.59.

Kaya, H. and Macit, M. 2012. Effect of inclusion of garlic (Allium sativum) powder at different levels and copper into diets of hens on performance, egg quality traits and yolk cholesterol content. International Journal of Poultry Science, 11: 114119. https://doi.org/10.3923/ijps.2012.114.119

Mohammadi Z., Ghazanfari, S. and Adib Moradi, M. 2014. Effect of supplementing clove essential oil to the diet on microflora population, intestinal morphology, blood parameters and performance of broilers European Poultry Science, 78:1-11.

Mukhtar AM. 2011. The effect of dietary clove oil on broiler performance. Australian Journal of Basic and Applied Sciences, 5(7): 49-51.

Najafi P, Torki M. 2010. Performance, blood metabolites and immunocompetence of broiler chicks fed diets included essentioal oils of medicinal herbs. Journal of Animal and Veterinary Advances, 9: 1164-1168. DOI: 10.3923/javaa.2010.1164.1168
NRC. 1994. National Research Council. Nutrient requirements of poultry. 9th ed. Washington; DC, USA: National Academy Press.

Placer ZA, Cushman LL, Johnson BC. 1966. Estimation of product of lipid peroxidation (malonyl dialdehyde) in biochemical systems. Anal Biochem, 16:359-364.

Saricaoglu FT, Turhan S. 2018. Antimicrobial activity and antioxidant capacity of thyme, rosemary and clove essential oils and their mixtures. Journal of Innovative Science and Engineering, 2: 25-33.

SPSS. 2011. Corp. Released, IBM SPSS Statistics for Windows, Version 20.0, IBM Corp., Armonk, NY.

Traesel CK, Wolkmer P, Schmidt C, Silva CB, Paim FC, Rosa AP, Alves SH, Santurio JM, Lopes STA. 2011. Serum biochemical profile and performance of broilerchickens fed diets containing essential oils and pepper. Comparative Clinical Pathology, 20:453-460. https://doi.org/10.1007/s00580-010-1018-1

TSE. 1991. HayvanYemleri- Metabolik (Çevrilebilir) Enerji Tayini (Kimyasal Metot). Türk Standartları Enstitüsü. TS 9610. UDK 636.085. Ankara.

Wang HF, Yih KH, Huang KF. 2010: Comparative study of the antioxidant activity of forty-five commonly used essential oils and their potential active components. Journal of Food and Drug Analysis, 18: 24-33. https://doi.org/10.38212/22246614.2225

Zhai H, Liu H, Wang S, Wu J, Kluenter AM. 2018. Potential of essential oils for poultry and pigs. Animal Nutrition, 4(2): 179-186. https://doi.org/10.1016/j.aninu.2018.01.005 